\title{
Relationship of Work Environment, Commitment, Compensation and Turnover Intention of Private Elementary School Teachers
}

\author{
M Hartono \\ Faculty of Humanities, Universitas Bina Nusantara, Jakarta, Indonesia \\ mhartono@binus.edu
}

\begin{abstract}
The purpose of this research is to find out the relationship between the work environment, commitment, compensation with turnover intention. Data were collected from 45 Al Irsyad Al Islamiyyah Pekalongan elementary school teachers. Al Irsyad Al Islamiyyah Pekalongan Elementary School is a private school but no teachers quitted within two years. This phenomenon is very interesting to be observed further. This research is a quantitative research with a questionnaire as its data collection method. The data analysis method chosen is Pearson correlation and regression. The findings show a negative relationship between work environment and turnover intention, commitment to turnover intention, compensation with turnover intention. The findings mean that really prove that the teachers will stay for a long time in Al Irsyad Al Islamiyyah Pekalongan Elementary School.
\end{abstract}

Keywords: Work Environment, Turnover Intention, Private School

\section{INTRODUCTION}

One of the main factors that determine the quality of education is the teacher. According to Sucipto [1] teachers are determinants of educational success through their performance at the institutional and experiential levels, so efforts to improve the quality of education must begin with the teacher aspect.

Problems become more complicated when there are many teachers who change jobs. Schools that have teachers who always change will have big problems to improve the quality of education.

In Indonesia, the phenomenon of teachers who always change the majority occurs in private schools. This happens because teachers in private schools are teachers who are not civil servants. Different from public schools where the teacher is a civil servant appointed by the government through the Ministry of Education. Teachers in public schools change because the teacher moves assignments or stops because of retirement

Before a teacher quit working, a process must be preceded. This process is the desire to stop working or is called turnover intention. Turnover is the process by which employees leave the organization and work position. the discharge of employees from the company will lead to higher costs incurred by the company to recruit employees and re-training costs [2], [3]. If it happened in the school, the discharge of teachers from the school will lead to higher costs 
incurred by the school to recruit teachers and re-training costs. Another effect felt by schools is that schools lose time and costs to train new teachers that should be used for improvement

One of the factors that influence turnover intention is compensation. A good compensation system will help companies avoid turnover intention [4]. This also applies at school. A good compensation system at school will prevent teacher turnover. Compensation and commitment variable have negative and significant effect of turnover intention [5]. According another study finding, based on statistically, there is significant negative correlation between turnover intention and work environment [6], [7].

According previous studies, there is a significant relation between commitment and turnover intention [8]. According another study, result demonstrate that the employees' perseption of high commitment compensation reduce the likelihood of their turnover intention $[9] .$.

Almost all research on turnover intentions takes place in companies or institutions whose number of human resources has stopped working high [6], [7], [9]-[11]. This research is different from other studies. This research took the population of an elementary school where there were no teachers who stopped working. This research took place at Al Irsyad Al Islamiyyah Pekalongan Elementary School in the city of Pekalongan. Al Irsyad Al Islamiyyah Pekalongan Elementary School is interesting to study because since the 2016/2017 academic year until the 2018/2019 academic year there are no teachers who quit working. It means that the teachers at Al Irsyad Al Islamiyyah Pekalongan Elementary School have a low level of turnover intention.

The purpose of this research is to find out the relationship between the work environment, commitment, compensation with turnover intention at Al Irsyad Al Islamiyyah Pekalongan Elementary School. The purpose of this research also proves whether the findings of previous studies on variable relationships carried out in institutions with high turnover are the same as the results of research with low turnover intention

The findings of this study are expected to be useful for other schools to maintain the sustainability of human resources, especially teachers. If there is no teacher quit within a certain period of time, the school will focus on improving the quality of teachers

\section{LITERATURE REVIEW}

\subsection{Literatur}

\subsubsection{Work Environment}

The work environment is the whole tool and material equipment faced, the surrounding environment in which a person works, his working methods, and work arrangements both as individuals and as a group. on things that are around and cover the work of employees in the office [12].

According to Sedarmayanti (2009) [12] the type of work environment is divided into physical work environment and non-physical work environment. The physical work environment consists of indicators: 1) lighting / light at the workplace; 2) temperature at workplace; 3) moisture at the workplace; 4) air circulation at the workplace; 5) noise at the workplace; 6) mechanical vibration at the workplace; 7) smells at workplace ; 8) color arrangements at workplace; 9) decoration at workplace; 10) music at workplace; and 11) workplace Safety 
Non-physical work environment is all the circumstances that occur relating to work relationships, both relationships with superiors and relationships with colleagues, or relationships with subordinates

\subsubsection{Commitment}

Mathis \& Jackson [13] define organizational commitment as the degree to which employees believe and are willing to accept organizational goals and will remain or will not leave their organization. Organizational commitment according to Soekidjan [14] can also mean strong individual acceptance of organizational goals and values, and individuals strive and work and have a strong desire to remain in the organization.

Meyer et al. [15] conceptualized organizational commitment in three career approaches, namely: 1) affective commitment; 2) normative commitment; and 3) continuance commitment.

\subsubsection{Compensation}

According to Hasibuan [16] compensation is all income in the form of money, goods directly or indirectly received by employees as compensation for those given to the company. Giving compensation is considered as compensation for the company to employees, so that by providing good compensation will make employees feel valued by the company. This valued feeling then makes employees stay in the company, because they assume that the company is aware of the existence of employees as an integral part of the company.

This type of compensation based on the nature of the income is divided into 1) direct compensation; and 2) indirect compensation. Direct compensation consists of: 1) wages, 2) salaries, and 3) bonuses. Indirect compensation consists of: 1) social security; 2) work leave; 3) retirement and 4) rest during working hours [17].

\subsubsection{Turnover Intention}

Turnover is the process by which employees leave the organization and work position. the discharge of employees from the company will lead to higher costs incurred by the company to recruit employees and re-training costs [2], [3].

Turnover is a real impact of turnover intention. According to Rony [18] turnover intention is a desire of employees to seek employment and alternative opportunities in other organizations or companies. Increased turnover intention can be detrimental to the company because this will have an impact on the attitude of the employees, employees who want to leave the company will tend to be more lazy and have a bad attitude towards their work which will be detrimental to the activities within the company.

According to Wateknya [11] the dimensions and indicators of turnover intention are: 1) think to quit ;2) intention to search for another job; and 3) intention to quit.

\subsection{Objective of the Study}

Objective of the study are:

1. To determine the relationship among work environment and turnover intention of private elementary school teachers 
2. To determine the relationship among commitment and turnover intention of private elementary school teachers

3. To determine the relationship among compensation and turnover intention of private elementary school teachers

\subsection{Framework and Hypothesis}

The conceptual framework of the relation between work environment, compensation, commitment and turnover intention in this study consisted of four variables can see at figure 1 .

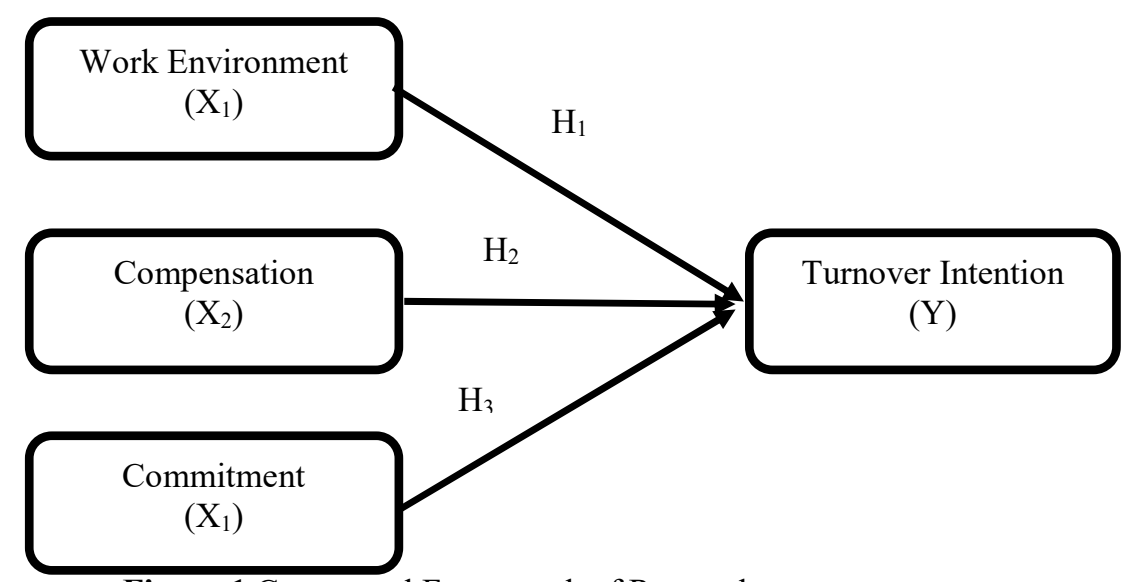

Figure 1.Conceptual Framework of Research.

Based on the problem formulation and the basic theory that has been described before, the hypothesis in this study are:

$\mathrm{H}_{01}$ : There is no significant relationship among work environment and turnover intention of private elementary school teachers

$\mathrm{H}_{02}$ : There is no significant relationship among commitment and turnover intention of private elementary school teachers

$\mathrm{H}_{03}$ : There is no significant relationship among compensation and turnover intention of private elementary school teachers

\section{RESULT AND DISCUSSION}

\subsection{Descriptive Analysis}

\subsubsection{Respondent Characteristics based on Gender}

Characteristics of respondents based on gender divided into 2 (two) categories : male and female. Using this categories, the validity calculation result based on gender according to Table 1.Based on Table 1, it is known that the gender of total of 30 respondents are as many as 
male $5(16.6 \%)$ and female $25(83.3 \%)$. It can be concluded the teachers in Al Irsyad Al Islamiyyah Pekalongan Elementary School dominated by woman.

Table 1. Teacher's Gender.

\begin{tabular}{cccccc}
\hline & & Frequency & Percent & Valid Percent & Cumulative Percent \\
\hline \multirow{4}{*}{ Valid } & Male & 5 & 16.7 & 16.7 & 16.7 \\
& Female & 25 & 83.3 & 83.3 & 100.0 \\
& Total & 30 & 100.0 & 100.0 & \\
\hline
\end{tabular}

\subsubsection{Respondent Characteristics based on Age}

Characteristics of respondents based on age divided into 6 (six) categories of age, i.e. : 2630 years, $31-35$ years, $36-40$ years, $41-45$ years, $45-50$ years, $>50$ years. Using this categories, the validity calculation result based on ageaccording to Table 2 .

Table 2. Teacher's Age

\begin{tabular}{cccccc}
\hline & Frequency & Percent & Valid Percent & $\begin{array}{c}\text { Cumulative } \\
\text { Percent }\end{array}$ \\
\hline \multirow{6}{*}{ Valid } & $26-30$ & 8 & 26.7 & 26.7 & 26.7 \\
& $31-35$ & 5 & 16.7 & 16.7 & 43.3 \\
& $36-40$ & 6 & 20.0 & 20.0 & 63.3 \\
& $41-45$ & 7 & 23.3 & 23.3 & 86.7 \\
& $45-50$ & 2 & 6.7 & 6.7 & 93.3 \\
& $>50$ & 2 & 6.7 & 6.7 & 100.0 \\
& Total & 30 & 100.0 & 100.0 & \\
\hline
\end{tabular}

Based on Table 2, it is known that the age of total of 30 respondents are as many as 8 (26.7\%) respondents $26-30$ years old, $5(16.7 \%)$ respondents $31-35$ years old. $6(20 \%)$ respondents $36-40$ years old, $7(23.3 \%)$ respondents $41-45$ years old, 2 (6.7\%) respondents $45-50$ years old, and $2(6.7 \%)$ respondents $>50$ years old. It can be concluded the teachers in Al Irsyad Al Islamiyyah Pekalongan Elementary School cumulatively there are $63.3 \%$ of teachers aged $<41$ years.

\subsubsection{Respondent Characteristics based on Marital Status}

Characteristics of respondents based on marital status divided into 2 (two) categories: unmarried and married. Using this categories, the validity calculation result based on marital status according to Table 3 .

Table 3.Teacher's Marital Status

\begin{tabular}{clcccc}
\hline & Frequency & Percent & Valid Percent & $\begin{array}{c}\text { Cumulative } \\
\text { Percent }\end{array}$ \\
\hline \multirow{3}{*}{ Valid } & Unmarried & 8 & 26.7 & 26.7 & 26.7 \\
& Married & 22 & 73.3 & 73.3 & 100.0 \\
& Total & 30 & 100.0 & 100.0 & \\
\hline
\end{tabular}


Based on Table 3, it is known that the gender of total of 30 respondents are as many as unmarried 8 (36.7\%) and married $22(73.3 \%)$. It can be concluded the teachers in Al Irsyad Al Islamiyyah Pekalongan Elementary School dominated by married marital status.

\subsubsection{Respondent Characteristics based on Work Length}

Characteristics of respondents based on age divided into 5 (FIVE) categories of work length, i.e. : $<5$ years, $6-10$ years, $11-15$ years, $16-20$ years, $>20$ years. Using this categories, the validity calculation result based on age According to Table 4.

Table 4. Teacher's Work Length

\begin{tabular}{clcccc}
\hline & & Frequency & Percent & Valid Percent & $\begin{array}{c}\text { Cumulative } \\
\text { Percent }\end{array}$ \\
\hline \multirow{4}{*}{ Valid } & $<5$ & 7 & 23.3 & 23.3 & 23.3 \\
& $11-15$ & 1 & 3.3 & 3.3 & 26.7 \\
& $16-20$ & 22 & 73.3 & 73.3 & 100.0 \\
& Total & 30 & 100.0 & 100.0 & \\
\hline
\end{tabular}

Based on Table 4, it is known that the age of total of 30 respondents are as many as 7 $(23.3 \%)$ respondents $<5$ years work length, 1 (3.3\%) respondents $11-15$ years work length, and $22(73.3 \%)$ respondents $16-20$ years work length. There is no respondents have $6-10$ years work length and there is no respondents $>20$ years work length. It can be concluded the teachers in Al Irsyad Al Islamiyyah Pekalongan Elementary School dominated by $16-20$ years work length

\subsection{Correlation Analysis}

The correlations between variables in this study can see in Table 5 .

Table 5. Correlations

\begin{tabular}{|c|c|c|c|c|c|}
\hline & & $\begin{array}{c}\text { Work } \\
\text { Environment }\end{array}$ & Compensation & Commitment & $\begin{array}{l}\text { Turnover } \\
\text { Intention }\end{array}$ \\
\hline \multirow{3}{*}{ Work Environment } & Pearson Correlation & 1 & $.666^{* *}$ & $.638^{* *}$ & $-.362^{*}$ \\
\hline & Sig. (2-tailed) & & .000 & .000 & .049 \\
\hline & $\mathrm{N}$ & 30 & 30 & 30 & 30 \\
\hline \multirow{3}{*}{ Compensation } & Pearson Correlation & $.666^{* *}$ & 1 & $.635^{* *}$ & $-.508^{* *}$ \\
\hline & Sig. (2-tailed) & .000 & & .000 & .004 \\
\hline & $\mathrm{N}$ & 30 & 30 & 30 & 30 \\
\hline \multirow{3}{*}{ Commitment } & Pearson Correlation & $.638^{* *}$ & $.635^{* *}$ & 1 & $-.593^{* *}$ \\
\hline & Sig. (2-tailed) & .000 & .000 & & .001 \\
\hline & $\mathrm{N}$ & 30 & 30 & 30 & 30 \\
\hline \multirow{3}{*}{ Turnover Intention } & Pearson Correlation & $-.362^{*}$ & $-.508^{* *}$ & $-.593^{* *}$ & 1 \\
\hline & Sig. (2-tailed) & .049 & .004 & .001 & \\
\hline & $\mathrm{N}$ & 30 & 30 & 30 & 30 \\
\hline
\end{tabular}

**. Correlation is significant at the 0.01 level (2-tailed).

*. Correlation is significant at the 0.05 level (2-tailed). 
Based on Table 4, it is known is known the relationship between work environment and turnover intention -0.362 , the relationship between compensation and turnover intention 0.508 and the relationship between commitment and turnover intention -0.593 . Based on the output it can be concluded that the relationship between work environment and turnover intention is weak in opposite directions, the relationship between compensation and turnover intention is strong in opposite directions and the relationship between commitment and strong turnover intention is opposite. This means if the work environment, compensation and commitment increase will make the turnover intention decrease or vice versa if the work environment, compensation and commitment decrease will make the turnover intention increase.

\section{CONCLUSION}

The results of the study indicated that the teachers in Al Irsyad Al Islamiyyah Pekalongan Elementary School are $63.3 \%$ of teachers aged $<41$ years, dominated by woman, dominated by married marital status and dominated by $16-20$ years work length. Based on this results, management of the school have to make a plan and anticipation strategy to anticipate if some time, simultaneously there are several teachers the maternity leave. The school management must have a plan for the recruitment process of new teachers considering that there are many teachers who have retired during a certain period of time

The results of the study indicated the weak relationship between work environment and turnover in opposite directions, the strong relationship compensation and turnover intention in opposite directions and the strong relationship between commitment and strong turnover intention in opposite directions. This means if the work environment, compensation and commitment increase will make the turnover intention decrease or vice versa if the work environment, compensation and commitment decrease will make the turnover intention increase. To prevent the occurrence of teachers quit, and decrease turnover intention, it must increase compensation and commitment.

The decrease in turnover intention means there is no teacher intends to quit. This means that the school has the sustainability of human resources, especially teachers. With the sustainability of teachers, the school is expected to focus on improving the quality of teachers to improve the quality of schools

\section{REFERENCES}

[1] M. and Iskandar, Orientasi Baru Supervisi Pendidikan. Jakarta: Gaung Persada, 2009.

[2] R. L. Mathis and J. H. Jackson, Human Resource Management. Jakarta: Salemba Empat, 2011.

[3] A. Cohen and R. Golan, "Predicting absenteeism and turnover intentions by past absenteeism and work attitudes," Career Dev. Int., vol. 12, no. 5, pp. 416-432, Aug. 2007.

[4] Putrianti, Hamid, and Mukzam, "Pengaruh lingkungan kerja fisik dan non fisik terhadap kinerja karyawan (Studi pada karyawan PT. Telkomsel Area III Jawa-Bali Nusra di Surabaya)," J. Adm. Bisnis, vol. 12, no. 2, pp. 1-9, 2014.

[5] R. D. Parashakti, M. Nashar, and D. Usliawati, "Advances in Intelligent Systems Research," in Proceedings of the 2017 International Conference on Organizational Innovation (ICOI 2017, 2017.

[6] B. Lee, D. Seo, J.-T. Lee, A.-R. Lee, H.-N. Jeon, and D.-U. Han, "Impact of work 
environment and work-related stress on turnover intention in physical therapists," $J$. Phys. Ther. Sci., vol. 28, no. 8, pp. 2358-2361, 2016.

[7] M. I. Qureshi, M. Iftikhar, S. G. Abbas, U. Hassan, K. Khan, and K. Zaman, "Relationship between job stress, workload, environment and employees turnover intentions: What we know, what should we know," World Appl. Sci. J., vol. 23, no. 6, pp. $764-770,2013$.

[8] D. M. McInerney, F. A. Ganotice, R. B. King, H. W. Marsh, and A. J. S. Morin, "Exploring commitment and turnover intentions among teachers: What we can learn from Hong Kong teachers," Teach. Teach. Educ., vol. 52, pp. 11-23, Nov. 2015.

[9] M. R. Basher Rubel and D. M. Hung Kee, "High Commitment Compensation Practices and Employee Turnover Intention: Mediating Role of Job Satisfaction," Mediterr. J. Soc. Sci., vol. 6, no. 6, Dec. 2015.

[10] N. H. Shah and N. B. Jumani, "Relationship of Job Satisfaction and Turnover Intention of Private Secondary School Teachers," Mediterr. J. Soc. Sci., vol. 6, no. 4, Jul. 2015.

[11] Y. Wateknya, "Pengaruh Komitmen Organisasi dan Kepuasan Kerja Terhadap Turnover Intention,” J. Manaj. Bisnis Indones., vol. 5, no. 5, pp. 468-480, 2016.

[12] Sedarmayanti, Sumber Daya Manusia dan Produktivitas Kerja. Bandung: CV Mandar Maju, 2009.

[13] R. L. Mathis and J. H. Jackson, Human Resource Management. Mason: South Western, 2008.

[14] S. Soegiarto, Komitmen Organisasi Sudahkah Menjadi Bagian Dari Kita? Jakarta: Rineka Cipta, 2009.

[15] J. P. Meyer, D. J. Stanley, L. Herscovitch, and L. Topolnytsky, "Affective, Continuance, and Normative Commitment to the Organization: A Meta-analysis of Antecedents, Correlates, and Consequences," J. Vocat. Behav., vol. 61, no. 1, pp. 20 52, Aug. 2002.

[16] M. Hasibuan, Manajemen Sumber Daya Manusia. Jakarta: PT Bumi Aksara, 2012.

[17] Triton, Manajemen Sumber Daya Manusia; Perspektif Partnership dan Kolektivitas. Bandung: Alfa Beta, 2007.

[18] Z. Rony, Siapa Harus Pergi Siapa harus Tinggal. Jakarta: PSDM, 2016. 